\title{
Polish Endogonaceae 1. Acaulospora bireticulata, Entrophospora infrequens, Glomus caledonium, and Scutellospora pellucida
}

\author{
JANUSZ BŁASZKOWSKI
}

\begin{abstract}
BŁASZKOWSKI, J. 1989: Polish Endogonaceae 1. Acaulospora bireticulata, Entrophospora infrequens, Glomus caledonium, and Scutellospora pellucida. - Karstenia 29:1-10.

The occurrence and distribution of four species of the Endogonaceae in Poland are described and illustrated. Entrophospora infrequens (Hall) Ames \& Schn., Glomus caledonium (Nicol. \& Gerd) Trappe \& Gerd., and Scutellospora pellucida (Nicol. \& Schenck) Walker \& Sanders probably occur in the whole of Poland, but in low frequencies, and Acaulospora bireticulata Rothw. \& Trappe seems to be a very rare species, having been found in only 2 of the 141 soil samples studied. G. caledonium is new to Poland and the other species were found for the first time in Europe.
\end{abstract}

Janusz Błaszkowski, Department of Plant Pathology, Academy of Agriculture, Słowackiego 17, PL-71434 Szczecin, Poland

\section{Introduction}

A wide range of plants form vesicular-arbuscular mycorrhizae (VAM) with fungi of the family Endogonaceae. Gerdemann (1968) recognized that these are possibly the most common of all soil fungi and that it would be easier to list families and genera of plants which do not enter into mycorrhizal connections with these fungi than those which do.

The VAM fungi are divided into six genera (Acaulospora Gerd. \& Trappe, Entrophospora Ames \& Schn., Gigaspora Gerd. \& Trappe, Glomus Tul. \& Tul., Sclerocystis Berk. \& Br., Scutellospora Walker $\&$ Sanders) and are primarily differentiated by the spore morphology (Gerdemann \& Trappe 1974, Walker \& Sanders 1986).

The occurrence and distribution of VAM fungi are best known in the U.S. and Canada (Gerdemann \& Trappe 1974, Nicolson \& Schenck 1979, Schenck \& Smith 1982, Berch \& Fortin 1984, Miller et al. 1985), and in New Zealand and Australia (Mosse \&
Bowen 1968, Tandy 1975, Hall \& Abbott 1984, McGee 1986). They have been found sporadically in Europe, viz. in France (Tulasne \& Tulasne 1845), Denmark (Lange 1956), Great Britain (Godfrey 1957, Hawker 1974), Italy (Fassi 1965, Puppi \& Riess 1982), Norway (Eckblad 1985), Finland (Karsten 1884), Sweden (Kers 1985), Czechoslovakia (Kubikova 1961, Bahadur 1970), Hungary (Szemere 1965), and the U.S.S.R. (Bucholtz 1912). They have also been reported in Taiwan (Wu \& Chen 1985), India (Battacharjee \& Mukerji 1980, Mukerji et al. 1983), Cuba (Ferrer \& Herrera 1980), Mexico and Japan (Trappe 1977).

There are only three reports of the occurrence of the Endogonaceae in Poland (Błaszkowski 1988). Since 1983 the author of this article has undertaken regular investigations on the occurrence and geographic distribution of this group of fungi in Poland, the results of which will be presented in this series. 


\section{Material and methods}

Each year soil samples were collected from the end of July to the end of November. They were taken from the root zone, from a depth of 5-20 cm, and then refrigerated until processing. The other methods and the general terms used in these studies are the same as those presented in an earlier paper (Błaszkowski 1988). In addition, a polyvinyl alcohol/glycerol/lactic acid solution (PVGL) (Koske \& Tessier 1983) was used in the morphological studies of spores and Munsell Soil Color Charts (Munsell Color Company, INC., Baltimore, Maryland 1954) in the observations on spore colour.

All collections were made by the author. They are preserved in PVL and PVGL on microscope slides or in small vials with $5 \%$ formalin and deposited in the Department of Plant Pathology (DPP), Academy of Agriculture, Szczecin, Poland.

\section{Acaulospora bireticulata Rothw. \& Trappe}

This species is distinguishable by the characteristic ornamentation of the outermost spore wall, which consists of a polygonal reticulum overlying the spore surface covered with rounded spines (Fig. 2). In the spores from Poland, the colour, size and dimensions of the structures forming the wall ornamentation agree with the original description. According to Walker's (1983) terminology, the wall structure of A. bireticulata spores consists of three walls: an outer, coloured, fairly thick (4-4.4 $\mu \mathrm{m}$ thick in Polish specimens), ornamented, unit wall (wall 1) in the wall group A, and two hyaline, $0.5 \mu \mathrm{m}$ and $\pm 1 \mu \mathrm{m}$ thick, membranous and unit inner walls (walls 2, 3) in the wall group B (Fig. 1).

The Polish collections lack the lateral hyphae tapering to globose to subglobose hyphal termini characteristic of species of the genus Acaulospora. These structures usually disappear from maturing spores or fall off during wet-sieving, leaving round scars (Trappe \& Schenck 1982), which are seen on the collections from Poland.

A. bireticulata spores are very similar to those of Scutellospora reticulata (Koske, Miller \& Walker) Walker \& Sanders, having the same ornamentation of the outermost spore wall, but even if the suspensorlike cell of $S$. reticulata spores is missing, the two species are easily distinguished by their spore wall structure (3-walled vs. 6-walled).

This species has earlier been found only four times: in a soil sample collected in the field under Sassafrans albidum (Nutt.) Ness, in Kentucky, and in a greenhouse pot culture with Zea mays L. established in the same soil (Rothwell \& Trappe 1979), under Centrosema pubescens L. in Florida (Schenck \& Smith 1982), and under Malus domestica Borkh. in Michigan (Miller et al. 1985).

In Poland $A$. bireticulata was found only twice (Table 1, Fig. 14). It is probably a rare species occurring in small densities.

\section{Material examined}

See Table 1; specimens deposited: $812-816$ and 957-959 (DPP).

\section{Entrophospora infrequens (Hall) Ames \&} Schn.

The spores from Poland are as described by Ames and Schneider (1979), though they usually lack, or possess only a fragment of the vesicle connected with the thin outer wall in which they were formed (Figs. 3, 4). In spite of this, the species is relatively easy to recognize by its characteristically ornamented spores (with vacuolated spines) with 3 walls (an evanescent, hyaline outermost wall; a laminate, coloured, ornamented middle wall; a unit, hyaline, smooth inner wall).

Table 1. Frequency of occurrence of Acaulospora bireticulata in Poland and chemical properties of soils from which this species was isolated.

\begin{tabular}{|c|c|c|c|c|c|c|c|}
\hline \multirow[t]{2}{*}{ Plant family } & \multirow[t]{2}{*}{ Plant species } & \multirow{2}{*}{$\begin{array}{c}\text { No. of } \\
\text { soil sample }\end{array}$} & \multirow{2}{*}{$\begin{array}{l}\text { No. of spores/ } \\
100 \text { g dry soil }\end{array}$} & \multicolumn{4}{|c|}{ Chemical properties } \\
\hline & & & & $\begin{array}{c}\mathrm{pH} \\
\text { (in } \mathrm{H}_{2} \mathrm{O} \text { ) }\end{array}$ & $\mathrm{NO}_{3}$ & $\begin{array}{c}\mathrm{P}_{2} \mathrm{O}_{5} \\
\left(\mathrm{mg} \mathrm{kg}^{-1}\right)\end{array}$ & $\mathrm{K}_{2} \mathrm{O}$ \\
\hline \multirow[t]{2}{*}{ Gramineae } & Triticum aestivum & 58 & 1 & 6.8 & 29 & 18 & 10 \\
\hline & Unknown grass & 99 & 5 & 5.1 & 10 & 14 & 9 \\
\hline
\end{tabular}


E. infrequens was originally reported from New Zealand by Hall (1977); since then it has been obtained from celery fields in central California, soils under poplar trees, soybean, and corn in Iowa, Illinois, and Wisconsin (Ames \& Schneider 1979), among the roots of Macroptilium sp. in Florida (Schenck \& Smith 1982), under Bouteloua gracilis (H.B.K.) Lag ex Steude and Agropyron smithii Rydb. in Wyoming (Stahl \& Christensen 1982), and under grasses of prairie and cultivated winter wheat in Kansas (Hetrick \& Bloom 1983) and Agave spp. in the Santa Catalina Mountains in Arizona (Bloss \& Walker 1987). The species has never been recorded earlier in Europe.

In Poland $E$. infrequens was found in six samples, taken under both cultivated and wild plants (Table 2, Fig. 14). Its spore density per $100 \mathrm{~g}$ dry soil ranged from 1 to 7 . This species probably occurs in the whole of Poland, but with low frequencies.

\section{Material examined}

See Table 2; specimens deposited: 668-674 and 964-966 (DPP).

Glomus caledonium (Nicol. \& Gerd.) Trappe \& Gerd.

In comparison with the original description of this species (Nicolson \& Gerdemann 1968), the spores from Poland are sometimes slightly larger (90-224$370 \mu \mathrm{m}$ in diam vs. 130-279 x 120-272 $\mu \mathrm{m})$ and usually have a considerably thicker wall (3.4-15.0 $26.9 \mu \mathrm{m} v s$. 6-10-16 $\mu \mathrm{m})$. Other features, permit the conclusion that the spores belong to $G$. caledo- nium, especially the 2-walled spore wall structure with a very characteristic, colourless, unit outer wall, easily separating from a yellow (5Y 8/8-2.5Y 8/8), laminate inner wall (wall 2), and the shape and dimensions of the subtending hyphae occluded by septa (Figs. 5-7). This species usually formed spores singly in the soil; sporocarps (Fig. 8) were found only in soil sample no. 88 (Fig. 15).

G. caledonium has earlier been identified in Scotland (Nicolson \& Gerdemann 1968), the U.S. (Gerdemann \& Trappe 1974, Menge et al. 1977, Miller et al. 1985), New Zealand and Australia (Hall 1977, Hall \& Abbott 1984). It has often been used in experimental research (e.g. Clarke \& Mosse 1981, Tommerup 1984, McGraw \& Hendrix 1984).

In Poland G. caledonium was isolated for the first time, from 16 soil samples (Fig. 15) taken under cultivated and wild plants. This species was the dominant symbiont of winter wheat crops at Lipki Experimental Station near Szczecin (soil samples no. 104 111).

\section{Material examined}

See Table 3; specimens deposited: 661-663, 675-684, 963, and 1020-1021 (DPP).

Scutellospora pellucida (Nicol. \& Schenck) Walker \& Sanders

The dimensions of the Polish spores, and especially their wall structure fit Koske and Walker's (1986) descriptions very well (Figs. 9-11). However, the spores are sometimes slightly darker having a hyaline to yellow (2.5Y 8/8) (vs. hyaline) inner wall in the

Table 2. Frequency of occurrence of Entrophospora infrequens in Poland and chemical properties of soils from which this species was isolated.

\begin{tabular}{|c|c|c|c|c|c|c|c|}
\hline \multirow[t]{2}{*}{ Plant family } & \multirow[t]{2}{*}{ Plant species } & \multirow{2}{*}{$\begin{array}{c}\text { No. of } \\
\text { soil sample }\end{array}$} & \multirow{2}{*}{$\begin{array}{l}\text { No. of spores/ } \\
100 \text { g dry soil }\end{array}$} & \multicolumn{4}{|c|}{ Chemical properties } \\
\hline & & & & $\begin{array}{c}\mathrm{pH} \\
\left(\text { in } \mathrm{H}_{2} \mathrm{O}\right)\end{array}$ & $\mathrm{NO}_{3}$ & $\begin{array}{c}\mathrm{P}_{2} \mathrm{O}_{5} \\
\left(\mathrm{mg} \mathrm{kg}^{-1}\right)\end{array}$ & $\mathrm{K}_{2} \mathrm{O}$ \\
\hline Cupressaceae & Juniperus communis & 98 & 2 & 5.1 & 10 & 14 & 9 \\
\hline \multirow[t]{3}{*}{ Gramineae } & Festuca rubra & 88 & 7 & 6.1 & 20 & 17 & 16 \\
\hline & Sorghum sudanense & 8 & 1 & 7.0 & 61 & 24 & 41 \\
\hline & Unknown grass & 99 & 2 & 5.1 & 10 & 14 & 9 \\
\hline Leguminosae & Trifolium repens & 1 & 7 & 5.4 & 19 & 22 & 14 \\
\hline Rosaceae & Rosa canina & 138 & 2 & 6.7 & 66 & 20 & 59 \\
\hline
\end{tabular}





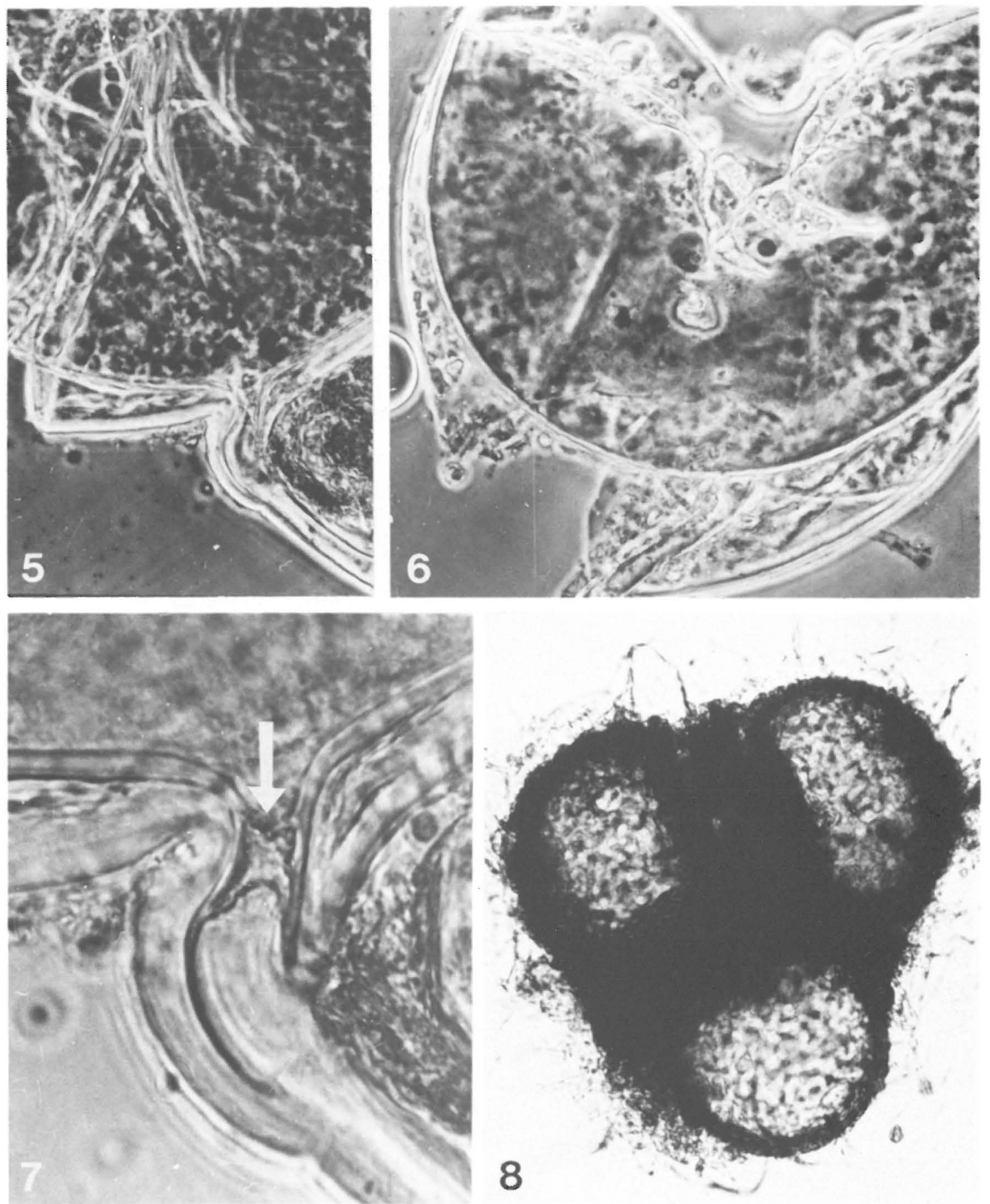

Figs. 1-4. Micrographs of the Endogonaceae. - 1: Acaulospora bireticulata, a crushed spore with 3 walls (arrows), phase contrast $(\mathrm{PC}), \times 255$. -2 : The reticulum and spines of the outermost wall can be seen, $\times 698$. - 3: Entrophospora infrequens, a spore with a fragment of the vesicle, PC, $\times 379$. - 4: A 3-walled spore; the outermost wall has been sloughed and only fragments are visible (arrow), PC, $\times 1200$.

Figs. 5-8. Glomus caledonium. -5 and 6: Crushed spores with separated walls, both PC, both $\times 400$. -7 : The spore base with the subtending hypha occluded by a septum (arrow); the very thick outer wall separated from the inner one is visible, $x 1200$. -8: A sporocarp, $\times 209$. 


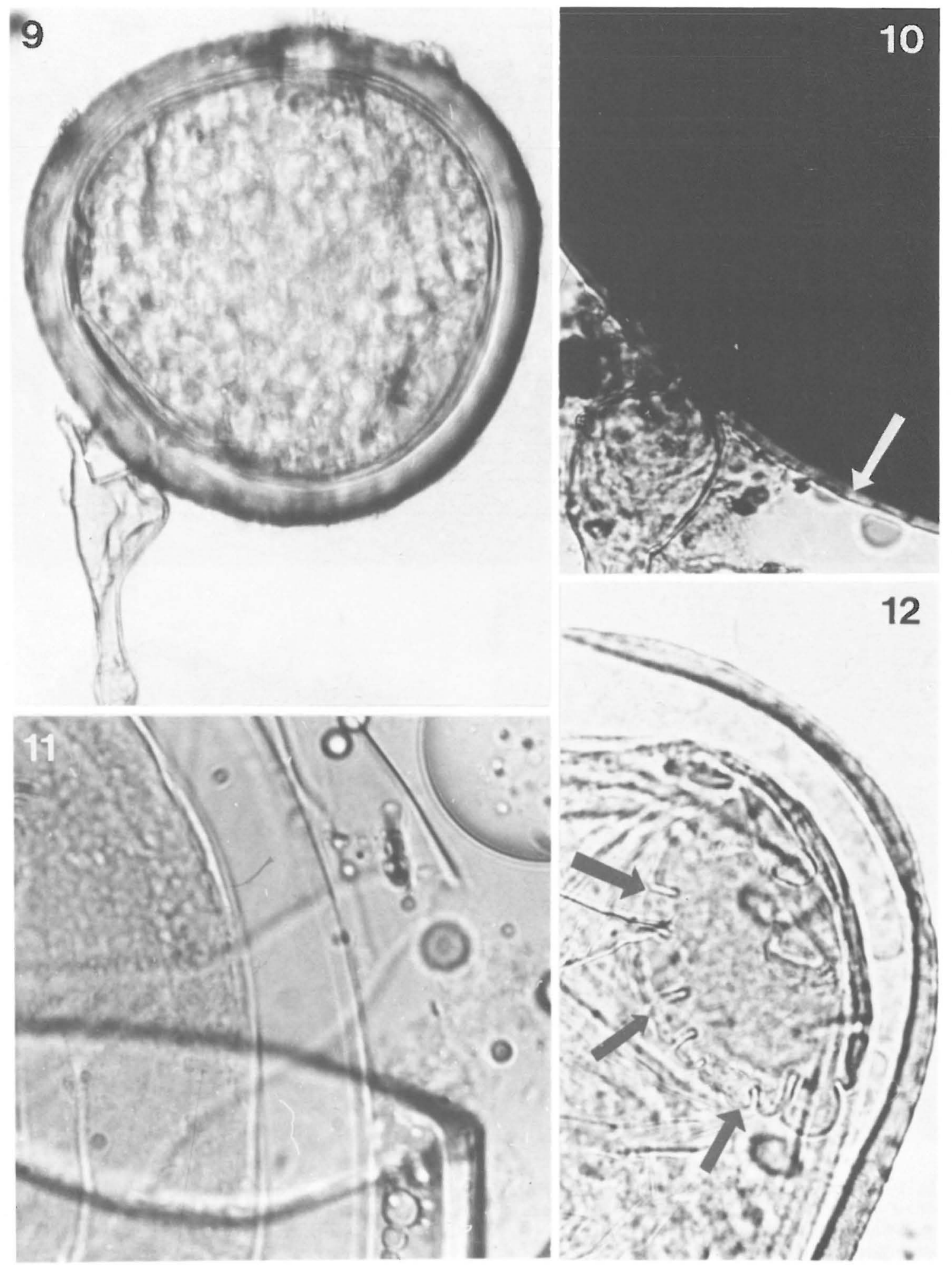

Figs. 9-12. Scutellospora pellucida. - 9: An intact spore, $\times 373$. - 10: A crushed spore in Melzer's reagent; the unit, unstained outermost wall is visible (arrow), x 820. - 11: A crushed spore showing spore walls, x 1370. - 12: Germination shield of a spore (arrows), $x 629$. 
Table 3. Frequency of occurrence of Glomus caledonium in Poland and chemical properties of soils from which this species was isolated.

\begin{tabular}{|c|c|c|c|c|c|c|c|}
\hline \multirow[t]{2}{*}{ Plant family } & \multirow[t]{2}{*}{ Plant species } & \multirow{2}{*}{$\begin{array}{c}\text { No. of } \\
\text { soil sample }\end{array}$} & \multirow{2}{*}{$\begin{array}{l}\text { No. of spores/ } \\
100 \mathrm{~g} \text { dry soil }\end{array}$} & \multicolumn{4}{|c|}{ Chemical properties } \\
\hline & & & & $\begin{array}{c}\mathrm{pH} \\
\text { (in } \mathrm{H}_{2} \mathrm{O} \text { ) }\end{array}$ & $\mathrm{NO}_{3}$ & $\begin{array}{c}\mathrm{P}_{2} \mathrm{O}_{5} \\
\left(\mathrm{mg} \mathrm{kg}^{-1}\right)\end{array}$ & $\mathrm{K}_{2} \mathrm{O}$ \\
\hline Buxaceae & Buxus sempervirens & 137 & 1 & 4.2 & 38 & 28 & 65 \\
\hline Cupressaceae & Thuja occidentalis & 102 & 12 & 5.1 & 38 & 11 & 29 \\
\hline \multirow[t]{4}{*}{ Gramineae } & Festuca rubra & 88 & 54 & 5.7 & 34 & 19 & 15 \\
\hline & Glyceria aquatica & 141 & 44 & 4.8 & 17 & 8 & 10 \\
\hline & Triticum vulgare & $104-111$ & $\begin{array}{l}29,32,18,10 \\
13,10,29,39\end{array}$ & $\begin{array}{l}4.4 \\
6.4\end{array}$ & $\begin{array}{l}21- \\
32\end{array}$ & $\begin{array}{l}6- \\
40\end{array}$ & $\begin{array}{c}7- \\
10\end{array}$ \\
\hline & Zea mays & 91 & 2 & 5.6 & 72 & 19 & 17 \\
\hline \multirow[t]{2}{*}{ Rosaceae } & Rosa canina & 123 & 2 & 3.9 & 24 & 15 & 16 \\
\hline & Rubus idaeus & 120 & 1 & 6.5 & 19 & 12 & 26 \\
\hline Solanaceae & Nicotiana tabacum & 103 & 10 & 4.5 & 46 & 11 & 6 \\
\hline
\end{tabular}

wall group A. The worst problem encountered in distinguishing $S$. pellucida spores from those of other light- and smooth-spored species is the difficulty of resolving the spore walls. Wall 1 (a unit outermost wall) was present in all the spores studied, though Melzer's reagent considerably simplified its observation, showing this wall as unstained and closely adhering to a laminate wall (wall 2) that stained dark red (10R 3/6) (Fig. 10). The inner walls in the group B (walls 3-5) posed the greatest problem. Wall 3 (a membranous wall) (Fig. 11) was easy to discern, but walls 4 and 5 (unit walls) were usually seen as a single, laminate or coriaceous wall adhering to an innermost wall (wall 6). All the three walls were best seen when the spores were crushed in PVGL. Wall 6 is amorphous in PVGL.

The features of the germination shields and suspensor-like cells (Figs. 9, 10, 12) also accord with Koske and Walker's description. The auxiliary cells of the Polish specimens are formed singly or in clusters in the soil; they are hyaline to reddish-yellow (7.5YR 7/8), 27-60 × 60-75 $\mu \mathrm{m}$, with blunt, rounded knobby projections, $15-17.5 \times 22.5-30 \mu \mathrm{m}$, produced on hyaline hyphae, $2.5-5.0 \mu \mathrm{m}$ in diam (Fig. 13). They have not been described by Koske and Walker. In comparison with those described by Nicolson and Schenck (1979), they are brighter (vs. brown) and somewhat larger (vs. 19-38 $\mu \mathrm{m}$ wide; projections $2-9 \times 5-15 \mu \mathrm{m})$. However, Koske and Walker (1985) recognized that the morphology of auxiliary cells is not especially useful in distinguish- ing species of the genus Scutellospora. The features of the germination shields have probably a similar significance. According to Koske and Walker (1986), S. pellucida is one of the most difficult species to determine.

S. pellucida was originally described from a soybean-rhizosphere soil in Florida (Nicolson \&

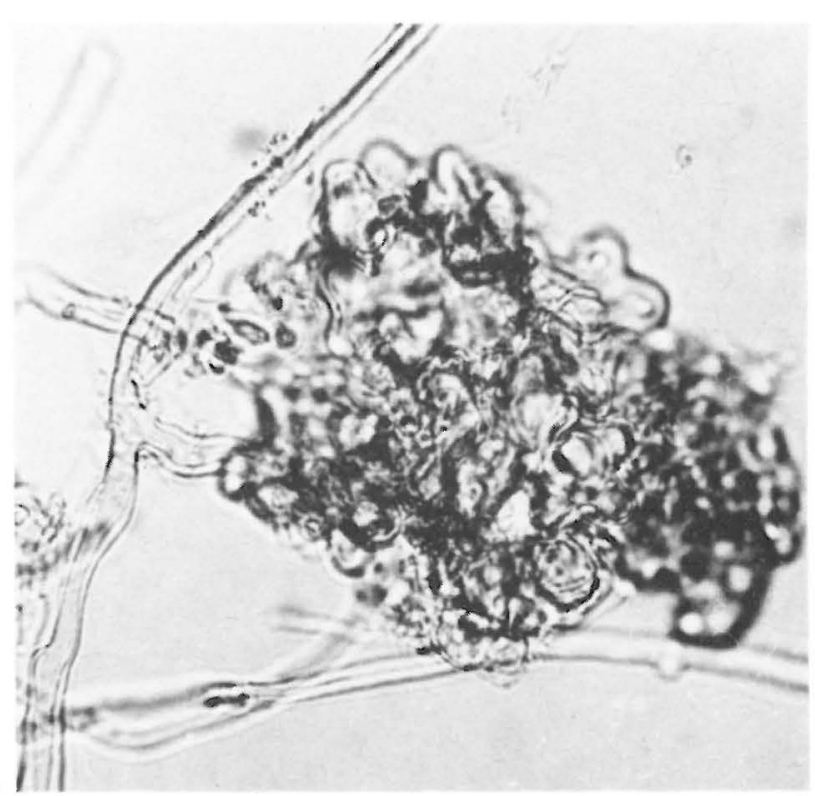

Fig. 13. Scutellospora pellucida, a cluster of auxiliary cells, $\mathbf{x}$ 702. 


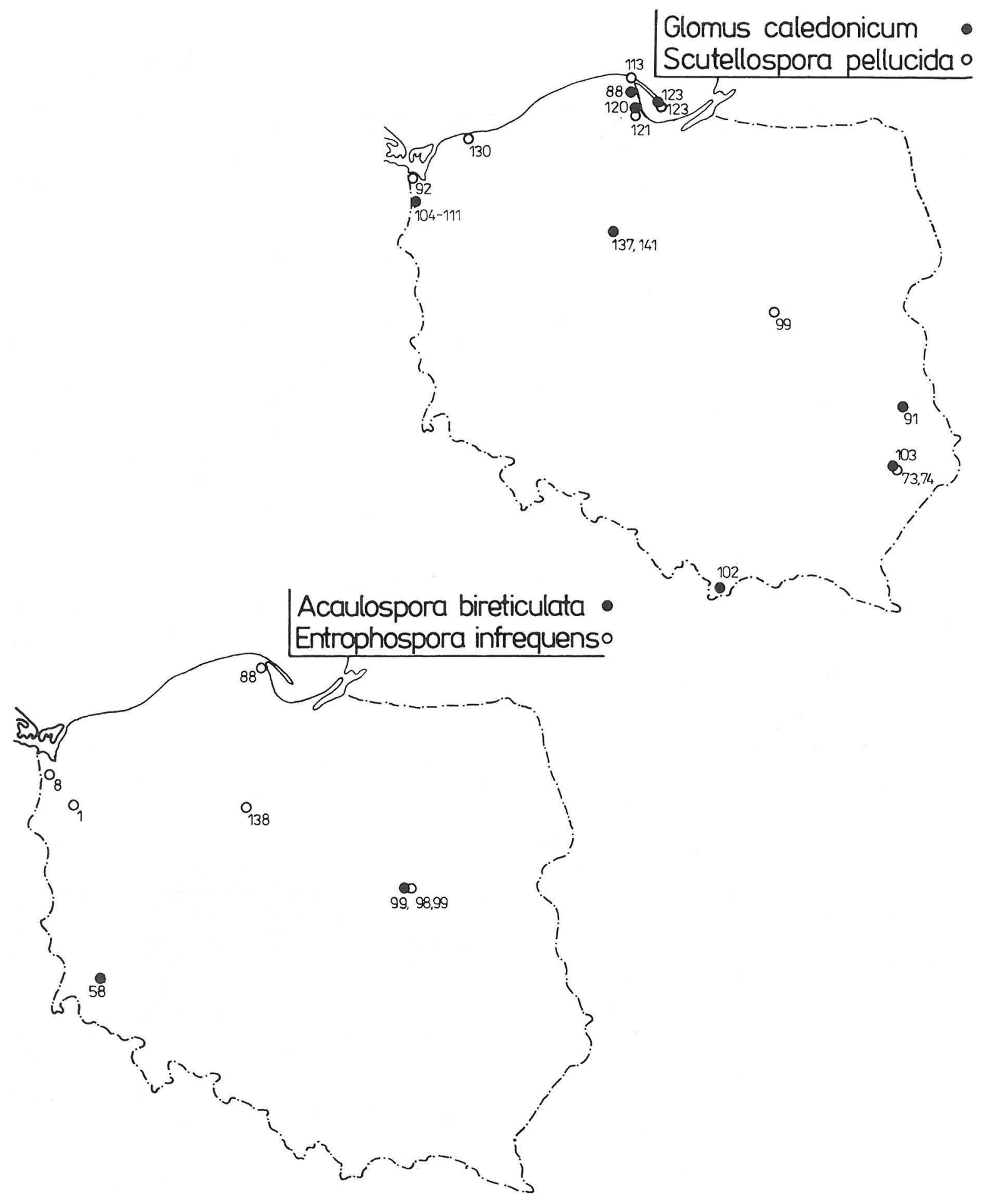

Figs. 14-15. Maps of the distribution of the Endogonaceae in Poland. - 14: Acaulospora bireticulata and Entrophospora infrequens in Poland. The numerals are the numbers of the soil samples. - 15: Glomus caledonium and Scutellospora pellucida in Poland. 
Table 4. Frequency of occurrence of Scutellospora pellucida in Poland and chemical properties of soils from which this species was isolated.

\begin{tabular}{|c|c|c|c|c|c|c|c|}
\hline \multirow[t]{2}{*}{ Plant family } & \multirow[t]{2}{*}{ Plant species } & \multirow{2}{*}{$\begin{array}{c}\text { No. of } \\
\text { soil sample }\end{array}$} & \multirow{2}{*}{$\begin{array}{l}\text { No. of spores/ } \\
100 \mathrm{~g} \text { dry soil }\end{array}$} & \multicolumn{4}{|c|}{ Chemical properties } \\
\hline & & & & $\begin{array}{c}\mathrm{pH} \\
\left(\text { in } \mathrm{H}_{2} \mathrm{O}\right)\end{array}$ & $\mathrm{NO}_{3}$ & $\begin{array}{c}\mathrm{P}_{2} \mathrm{O}_{5} \\
\left(\mathrm{mg} \mathrm{kg}^{-1}\right)\end{array}$ & $\mathrm{K}_{2} \mathrm{O}$ \\
\hline \multirow[t]{2}{*}{ Gramineae } & Festuca rubra & 73 & 45 & 5.8 & 22 & 21 & 19 \\
\hline & Unknown grass & 99 & 2 & 5.1 & 10 & 14 & 9 \\
\hline \multirow[t]{5}{*}{ Rosaceae } & Crataegus monogyna & $113,121,130$ & $1,3,2$ & 4.4 & 19 & 10 & 14 \\
\hline & & & & 6.2 & 160 & 22 & 25 \\
\hline & Malus domestica & 92 & 1 & 5.7 & 74 & 26 & 12 \\
\hline & Prunus domestica & 74 & 4 & 6.6 & 60 & 15 & 15 \\
\hline & Rosa canina & 123 & 15 & 3.9 & 24 & 15 & 16 \\
\hline
\end{tabular}

Schenck 1979). Since then, it has been found among many cultivated (Schenck \& Kinloch 1980, Schenck \& Smith 1981, Hetrick \& Bloom 1983, Miller et al. 1985 ) and wild plants (Rose 1980, Hetrick \& Bloom 1983). Koske and Walker (1986) and Koske (1987) found it to be a frequent associate with plants of sand dunes. This species was known only from the U.S.

In Poland $S$. pellucida was found in 8 of the 141 soil samples examined (Table 4, Fig. 15). It occurred only in soil samples taken under natural plants. Its spore density was generally low, ranging from 1 to 45 per $100 \mathrm{~g}$ dry soil. It seems that $S$. pellucida oc- curs in the whole of Poland, but with low frequencies.

\section{Material examined}

See Table 4; specimens deposited: 468-508, 839-840, and 982-1002 (DPP).

Acknowledgement. For constructive suggestions, I am grateful to Dr. S.M. Berch (Canada).

\section{References}

Ames, R.N. \& Schneider, R.W. 1979: Entrophospora, a new genus in the Endogonaceae. - Mycotaxon 8:374352.

Bahadur, A. 1970: Sporocarps of an Endogone species associated with the roots of Nardus plant. - Ceská Mycol. 24:166-176.

Berch, S.M. \& Fortin, J.A. 1984: Some sporocarpic Endogonaceae from eastern Canada. - Canad. J. Bot. 62:170-180.

Bhattacharjee, M. \& Mukerji, K.G. 1980: Studies on Indian Endogonaceae 2. The genus Glomus. - Sydowia 33:14-17.

Błaszkowski, J. 1988: Four new species of the Endogonaceae (Zygomycotina) from Poland. - Karstenia 27:37-42.

Bloss, H.E. \& Walker, C. 1987: Some endogonaceous mycorrhizal fungi of the Santa Catalina Mountains in Arizona. - Mycologia 79:649-654.
Bucholtz, F. 1912: Beiträge zur Kenntnis der Gattung Endogone Link. - Beih. Bot. Zbl. 29:147-224.

Clarke, C. \& Mosse, B. 1981: Plant growth responses to vesicular-arbuscular mycorrhiza 12 . Field inoculation responses of barley at two soil P levels. - New Phytol. 87:695-703.

Eckblad, F.E. 1985: Three hypogeous fungi new to Norway. - Agarica 6:104-107.

Fassi, B. 1965: Micorrize ectotrofiche di Pinus strobus L. prodotte da un Endogone (Endogone lactiflua Berk.). Allionia 11:7-15.

Ferrer, R.L. \& Herrera, R.A. 1980: El genero Gigaspora Gerdemann et Trappe (Endogonaceae) en Cuba. Rev. Jard. Bot. Nac., Univ. Habana 1:43-66.

Gerdemann, J.W. 1968: Vesicular-arbuscular mycorrhiza and plant growth. - Annu. Rev. Phytopathol. 6:397418 . 
Gerdemann, J.W. \& Trappe, J.M. 1974: The Endogonaceae in the Pacific Northwest. - Mycologia Memoirs 5:1-76.

Godfrey, R.M. 1957: Studies of British species of Endogone 1. Morphology and taxonomy. - Trans. British Mycol. Soc. 40:136-144.

Hall, I.R. 1977: Species and mycorrhizal infections of New Zealand Endogonaceae. - Trans. British Mycol. Soc. 68: 341-356.

Hall, I.R. \& Abbott, L.K. 1984: Some Endogonaceae from south western Australia. - Trans. British Mycol. Soc. 83:203-208.

Hawker, L.E. 1974: Revised annotated list of British hypogeous fungi. - Trans. British Mycol. Soc. 63:67-76.

Hetrick, B.A. \& Bloom, J. 1983: Vesicular-arbuscular mycorrhizal fungi associated with native tall grass prairie and cultivated winter wheat. - Canad. J. Bot. 61:21402146.

Karsten, P.A. 1884: Fragmenta mycologica. - Hedwigia 23:39-40.

Kers, L.E. 1985: Endogone flammicorona och Glomus versiforme nya for Sverige. - Svensk Bot. Tidskr. 79:175-185.

Koske, R.E. 1987: Distribution of VA mycorrhizal fungi along a latitudinal temperature gradient. - Mycologia 79:55-68.

Koske, R.E. \& Tessier, B. 1983: A convenient, permanent slide mounting medium. - Mycol. Soc. Am. Newsl. 34:59.

Koske, R.E. \& Walker, C. 1985: Species of Gigaspora (Endogonaceae) with roughened outer walls. - Mycologia 77:702-720.

- 1986: Species of Scutellospora (Endogonaceae) with smooth-walled spores from maritime sand dunes: two new species and a redescription of the spores of Scutellospora pellucida and Scutellospora calospora. - Mycotaxon 27:219-235.

Kubikova, J. 1961: Endogone sp. in association with vesicular-arbuscular mycorrhiza of ash (Fraxinus excelsior L.). — Ceská Mycol. 15:161-164.

Lange, M. 1956: Danish hypogeous Macromycetes. Dansk Bot. Arkiv 16:5-84.

McGee, P.A. 1986: Further sporocarpic species of Glomus (Endogonaceae) from South Australia. - Trans. British Mycol. Soc. 87:123-129.

McGraw, A.C. \& Hendrix, J.W. 1984: Host and soil fumigation effects on spore population densities of species of endogonaceous mycorrhizal fungi. - Mycologia 76:122-131.

Menge, J.A., Nemec, S., Davis, R.M. \& Minassian, V. 1977: Mycorrhizal fungi associated with citrus and their possible interactions with pathogens. - Proc. Int. Soc. Citriculture 3:872-876.

Miller, D.D., Domoto, P.A. \& Walker, C. 1985: Mycorrhizal fungi at eighteen apple rootstock plantings in the United States. - New Phytol. 100:379-391.

Mosse, B. \& Bowen, D.G. 1968: A key to the recognition of some Endogone spore types. - Trans. British Mycol. Soc. 51:469-483.
Mukerji, B.K., Bhattacharjee, M. \& Tewari, J.P. 1983: New species of vesicular-arbuscular mycorrhizal fungi. - Trans. British Mycol. Soc. 81:641-643.

Nicolson, T.H. \& Gerdemann, J.W. 1968: Mycorrhizal Endogone species. - Mycologia 60:313-325.

Nicolson, T.H. \& Schenck, N.C. 1979: Endogonaceous mycorrhizal endophytes in Florida. - Mycologia 71:178-198.

Puppi, G. \& Riess, S. 1982: Notes on the occurrence of endogonaceous spores and vesicular-arbuscular mycorrhizal associations in woodland sites in the middle valley of the Tiber (Italy). - Atti Accad. Naz. Lincei 72:279-284.

Rose, S.L. 1980: Mycorrhizal associations of some actinomycete nodulated nitrogen-fixing plants. - Canad. J. Bot. 58:1449-1454.

Rothwell, F.M. \& Trappe, J.M. 1979: Acaulospora bireticulata sp. nov. - Mycotaxon 8:471-475.

Schenck, N.C. \& Kinloch, R.A. 1980: Incidence of mycorrhizal fungi on six field crops in monoculture on a newly cleared woodland site. - Mycologia 72:445-456.

Schenck, N.C. \& Smith, G.S. 1981: Distribution and occurrence of vesicular-arbuscular mycorrhizal fungi on Florida agricultural crops. - Soil and Crop Sci. Florida, Proc. 40:171-175.

- 1982: Additional new and unreported species of mycorrhizal fungi (Endogonaceae) from Florida. - Mycologia 74:7792.

Szemere, L. 1965: Die unterirdischen Pilze des Karpatenbeckens. -319 pp. Budapest.

Stahl, P.D. \& Christensen, M. 1982: Mycorrhizal fungi associated with Bouteloua and Agropyron in Wyoming sagebrush-grasslands. - Mycologia 74:877-885.

Tandy, P.A. 1975: Sporocarpic species of Endogonaceae in Australia. - Aust. J. Bot. 23:849-866.

Tommerup, I.C. 1984: Effect of soil water potential on spore germination by vesicular-arbuscular mycorrhizal fungi. - Trans. British Mycol. Soc. 83:193-202.

Trappe, J.M. 1977: Three new Endogonaceae: Glomus constrictus, Sclerocystis clavispora, and Acaulospora scrobiculata. - Mycotaxon 6:359-366.

Trappe, J.M. \& Schenck, N.C. 1982: Taxonomy of the fungi forming endomycorrhizae A. Vesicular-arbuscular mycorrhizal fungi (Endogonales). - In: Schenck, N.C. (ed.), Methods and principles of mycorrhizal research, American Phytopathological Society, St. Paul, MN: 1-9.

Tulasne, L.R. \& Tulasne, C. 1851: Fungi hypogaei. 222 pp. Paris.

Walker, C. 1983: Taxonomic concepts in the Endogonaceae: spore wall characteristics in species descriptions. - Mycotaxon 18:443-455.

Walker, C. \& Sanders, F.E. 1986: Taxonomic concepts in the Endogonaceae 3. The separation of Scutellospora gen. nov. from Gigaspora Gerd. \& Trappe. - Mycotaxon 27:169-182.

Wu, C.C. \& Chen, Z.C. 1985: The distribution and association of endomycorrhizal fungi in bamboo forest (Phyllostachys pubescens Mazel) of Chi-Tou area in Taiwan 1. A preliminary investigation on endomycorrhizae in bamboo forest. - Trans. Mycol. Soc. Rep. China 1:41-51. 